\title{
UTRICULARIETUM AUSTRALIS TH. MÜLLER ET GÖRS 1960 IN POLAND
}

\author{
KRZYSZTOF SPAŁEK \\ Laboratory of Geobotany and Plant Conservation \\ Department of Biosystematics University of Opole \\ Oleska 22, 45-052 Opole, Poland \\ e-mail:kspalek@uni.opole.pl
}

(Received: January 5, 2006. Accepted: May 23, 2006)

\begin{abstract}
The paper presents the distribution, floristic composition and ecological requirements of the pleustonic plant community Utricularietum australis Th. Müller et Görs 1960 in Poland. The association was classifield to the Lemnetea minoris class. Utricularietum australis is considered to be a rare and endangered plant community in Europe.
\end{abstract}

KEY WORDS: Utricularietum australis, Lemnetea minoris class, distribution, phytosociology, Poland, endangered association.

\section{INTRODUCTION}

Utricularietum australis Th. Müller et Görs 1960 was first recognized in Baden-Württemberg in Germany in miry holes and peat extraction pits (Müller and Görs 1960). Subsequently, it has been found in other regions of Germany (Hilbig 1971; Dierschke and Tüxen 1975; Müller 1977; Franke 1986; Vahle and Preising 1990; Passarge 1996; Do11 1991; Wittig and Esser 1991; Pott 1995; Wageringel and Remy 1997; Hofmann 2001) and in Austria (Schratt 1993). Patches with domination of Utricularia australis have been reported also from Hungary (Kárpáti 1963) and the Danube valley in Slovakia (Ot'ahel'ová 1980). This community occurs in shallow $(50-150 \mathrm{~cm})$, oligotrophic or mesotrophic aciduous ( $\mathrm{pH}$ 5.0-6.0) ponds in peatbogs, ponds formed after peat extraction, fishponds, peaty ditches (Hilbig 1971; Dierschke and Tüxen 1975; Müller 1977; Franke 1986; Vahle and Preising 1990; Passarge 1996; Doll 1991; Schratt 1993; Pott 1995; Wageringel and Remy 1997; Hofmann 2001). In Hungary and Slovakia Utricularietum australis has been reported from mesotrophic standing waters (Kárpáti 1963; Ot'ahel'ová 1980). The characteristic and dominant species of Utricularietum australis is Utricularia australis. The differential species for this association are Potamogeton natans (Müller and Görs 1960; Hofmann 2001) and Sphagnum denticulatum, Lemna minor, Myriophyllum verticillatum (Hofmann 2001). This association is considered to be poor in species and consists of about 3-9 taxa on an average (Müller and Görs 1960; Müller 1977; Hofmann 2001). Species as Potamogeton natans, Spirodela polyrhiza, Lemna trisulca, Lemna minor, Ricciocarpos natans, Riccia fluitans and Potamogeton pusillus (Müller and Görs 1960; Hilbig 1971; Müller 1977; Hofmann 2001) attain a higher constancy index. Until present only two sub- communities of this association: with Potamogeton pusillus and Lemna trisulca (Müller 1977) have been described.

Utricularia australis was observed in scattered positions all over Poland (Zając and Zając 2001). The greatest numbers of it were recorded in Lower and upper Silesia and on Western Pomerania (Żukowski 1974). Most positions of this species come from the turn of 19th and 20th centuries (Żukowski 1974), therefore most of them have to be considered as historical. After 1945 it was observed considerably less frequently. In most of the given positions it is present individually in shallow lentic wates, or in very slowly flowing waters (e.g. Wołek 1971; Sendek 1984; Żukowski et al. 1995; Nowak et al. 2000). This species was observed in Nupharo-Nymphaetum (Żukowski 1974) and in Lemno minoris salvinietum natantis (Tomaszewicz 1979). In Poland until now Utricularietum australis were observed in the area around Staszów in the region of the Małopolska Upland (Ochyra 1985). One relevé provided by Krzywański (1974) presenting an old river bed of the middle Warta river in Lemno-Utricularietum chart, without any doubt represents also this association. Around Staszów Utricularietum australis was formed in former turf pits and on transition peat-bogs in Pocieszka and Czajków in shallow waters (30-40 cm) with pH 5.5-6 (Ochyra 1985).

Utricularietum australis belongs to the class Lemnetea minoris, which includes primitive pleustonic communities, which form aggregations on surface of standing or slowly 
running waters, mainly in eutrophic and mesotrophic, more rarely - distrophic water reservoirs. These communities often form a complex with higher organised phytocenoses of aquatic plants from the class Potametea (e.g. Oberdorfer 1977; Schwabe-Braun and Tüxen 1981; Landolt 1982; Wołek 1991, 1997; Pott 1995; Schubert et al. 1995; Matuszkiewicz 2005). This pleustonic plant community is recognized as endangered on both regional and Central European scale (Schratt 1993; Pott 1995; Rennwald 2000).

This paper describes the Utricularietum australis community. The phytosociological table is given and floristic composition and ecological requirements of that community are discussed.

\section{METHODS}

The fieldwork was conducted during vegetation seasons 1999 and 2001. The Utricularietum australis community was studied following the Zurich-Montpellier School of Phytosociology (Braun-Blanquet 1964). Phytosociological nomenclature and syntaxonomical attachment are based on Oberdorfer (1994) and Pott (1995). Vascular plant species names are given according to Mirek et al. (2002), and bryophytes to Frahm and Frey (1992). Hydrogen ion concentration was measured with Elmetron $\mathrm{pH}$ microcomputer CP-315.

\section{RESULTS}

During geobotanical investigations carried out in southwestern Poland two new localities of Utricularietum australis were discovered. These localities are situated in the Nature Reserve "Jeleniak-Mikuliny" near Lubliniec, and a fishpond in village Lasowice Małe near Kluczbork in Silesia (Fig. 1). The total coverage of the community in 2001 was up to 0.2 ha in the Nature Reserve "Jeleniak-Mikuliny", and 0.1 ha near Lasowice Małe. Utricularietum australis develops in insolated sites, screened from the wind by bushes or rushes, in water of depth $20-50 \mathrm{~cm}$ and $\mathrm{pH} 6.2$ to

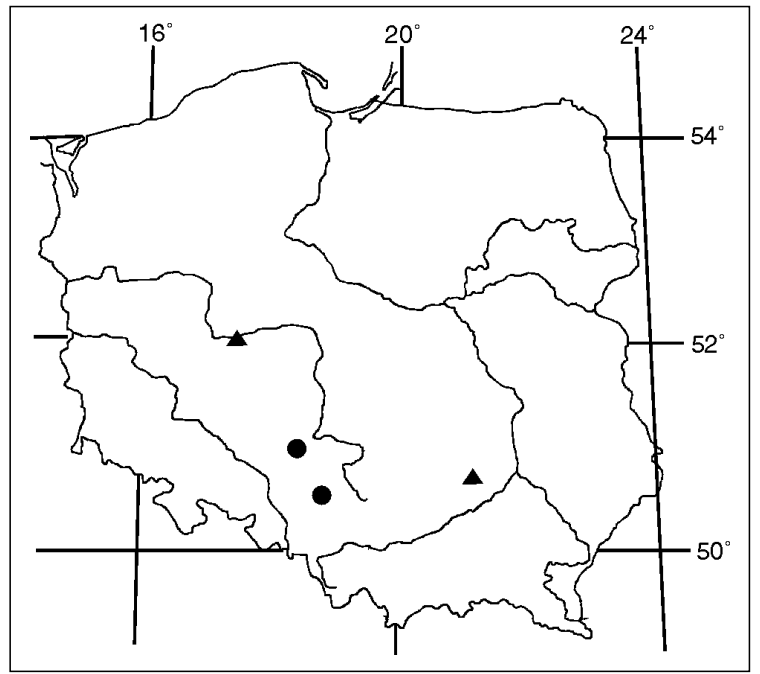

Fig. 1. Localities of Utricularietum australis in Poland. $\bullet$ - new locality, $\Delta$ - locality from the literature.
6.7. In this community Utricularia australis predominates (Table 1). There also occur, but with lower participation, e.g. Potamogeton natans and Lemna trisulca. Considering occurrences of the latter species, patches of this community should be assigned to the sub-community with Lemna trisulca (Müller 1977). Utricularietum australis built a micromosaic complex with Potametum natantis and Phragmitetum australis associations along southern edges of the ponds. However, the newly discovered localities are characterised by higher species-richness index in comparison with communities described until present. Opposite to the earlier described patches of this association, in Poland in this community a well-developed bryophyte layer can be distinguished, with species from the genus Sphagnum sp. Usually they are Sphagnum fallax and Sphagnum denticulatum (Table 1). The average species number in the relevé equals 6 . The overall number of species observed in examined Utricularietum australis segments on newly discovered positions in southwestern Poland is 13 , and is close to the number of the species of this group in analogical turf waters in northwestern Germany where the total of 11 species were observed (Hofmann 2001). In phytocoenosis of this group present in Silesia, as distinguished from its segments from Staszów area (Ochyra 1985) and in Germany (Müller and Görs 1960; Hilbig 1971; Müller 1977; Hofmann 2001), Lemna minor was not represented significantly. Similarily as in earlier described phytocoenosis described from Germany (Müller and Görs 1960; Hilbig 1971; Müller 1977; Hofmann 2001) and from Poland (Krzywański 1974; Ochyra 1985), the structure of Utricularietum australis segments in southwestern Poland is characterized by a definite two-layer structure. Utricularia australis with smaller quantity of Lemna trisulca, Sphagnum fallax and Sphagnum denticulatum dominates in the underwater layer. Layer above the waterline is formed by Potamogeton natans with some quantity of Lemna minor and Alisma plantago-aquatica.

Stands of Utricularietum australis in Poland should be covered with species protection. One of them, in the reserve "Jeleniak-Mikuliny" is already covered with protection. The pond in Laskowice Małe is also planned to be protected by law as a nature reserve. At present it is covered with protection as the area of ecological use in the local conservation strategy of the Kluczbork commune.

A complete phytosociological and habitat characteristic as well as the present distribution of Utricularietum australis in Poland should be a subject of further botanical investigations.

\section{SYSTEMATICAL POSITION OF THE COMMUNITY}

Class: Lemnetea minoris R. Tx. 1955

Order: Hydrocharitetalia Rübel 1933

Alliance: Hydrocharition Rübel 1933

Association: Utricularietum australis Th. Müller et Görs 1960

\section{ACKNOWLEDGEMENTS}

I wish to thank Prof. W. Pott, Institut für Geobotanik, Hannover, Prof. H. Tomaszewicz, Warsaw University, 
TABLE 1. Utricularietum australis Th. Müller et Görs 1960.

\begin{tabular}{|c|c|c|c|c|c|c|}
\hline Relevé number & & 1 & 2 & 3 & 4 & 5 \\
\hline Date: year & & 1999 & 1999 & 1999 & 2000 & 2001 \\
\hline month & & 07 & 07 & 07 & 07 & 08 \\
\hline day & & 04 & 04 & 04 & 11 & 09 \\
\hline Locality & & $\mathrm{JM}$ & $\mathrm{JM}$ & $\mathrm{JM}$ & LM & LM \\
\hline Cover of herb layer $[\%]$ & & 25 & 15 & 15 & 20 & 15 \\
\hline Cover of moss layer [\%] & & 15 & 5 & - & 5 & + \\
\hline Area of relevé $\left[\mathrm{m}^{2}\right]$ & & 10 & 10 & 8 & 10 & 10 \\
\hline Number of species in relevé & & 10 & 5 & 3 & 7 & 4 \\
\hline \multicolumn{7}{|c|}{ Ch., D.* Utricularietum australis } \\
\hline Utricularia australis & & 2 & 2 & 2 & 2 & 2 \\
\hline Potamogeton natans* & & 1 & + & + & + & • \\
\hline Sphagnum denticulatum* & $\mathrm{d}$ & 1 & - & - & + & • \\
\hline Lemna minor* & & + & - & - & - & + \\
\hline Potamogeton pusillus* & & - & + & • & - & - \\
\hline \multicolumn{7}{|c|}{ D. Utricularietum australis lemnetosum trisulcae } \\
\hline Lemna trisulca & & • & + & 1 & • & 1 \\
\hline \multicolumn{7}{|l|}{ Ch. Potametea } \\
\hline Alisma plantago-aquatica & & + & - & - & + & • \\
\hline \multicolumn{7}{|l|}{ Ch. Phragmitetea } \\
\hline Carex rostrata & & + & - & - & + & • \\
\hline \multicolumn{7}{|l|}{ Accompanying species } \\
\hline Sphagnum fallax & d & 2 & 2 & - & 2 & + \\
\hline
\end{tabular}

Sporadic species: Lemnetea minoris: Hydrocharis morsus-ranae + (1). Potametea: Nuphar lutea + (1). Phragmitetea: Equisetum fluviatile + (4); Phragmites australis $+(1)$.

Explanation: JM - Jeleniak-Mikuliny Nature Reserve; LM - Lasowice Małe; Ch. - characteristic species; D. - differential species; d - moss taxa

Prof. W. Żukowski, The Adam Mickiewicz University in Poznań, for cooperation and Dr A. Stebel, Medical University of Silesia, Katowice, for determination of moss taxa.

\section{LITERATURE CITED}

BRAUN-BLANQUET J. 1964. Pflanzensoziologie, Grundzüge der Vegetationskunde. Dritte Auflage. Springer Verlag, Wien-New York.

FRAHM J.-P., FREY W. 1992. Moosflora. Ed. 3. E. Ulmer, Stuttgart.

DIERSCHKE H., TÜXEN R. 1975. Die Vegetation des Langholter- und Rhauder Meeres und seiner Randgebiete. Mitt. flor.soz. Arbeitsgem. N. F. 18: 157-202.

DOLL R. 1991. Die Pflanzengesellschaften der stehenden Gewässer in Mecklemburg-Vorpommern. Teil I. 2./3. Fedd. Repert. 102 (3/4): 199-317.

FRANKE T. 1986. Pflanzengesellschaften der Fränkischen Teichlandschaft. Ber. Naturf. Ges. Bamberg 61 (12): 1-192.

HILBIG W. 1971. Übersicht über die Pflanzengesellschaften des südlichen Teiles der DDR. 1. Die Wasserpflanzengesellschaften. Hercynia 8 (1): 4-33.

HOFMANN K. 2001. Standortökologie und Vergesellschaftung der Utricularia - Arten Nordwestdeutschlands. Abh. Westf. Mus. f. Naturk. 63 (1): 3-106.

KÁRPÁTI V. 1963. Die zönologischen und ökologischen Verhältnisse der Wasservegetation des Donau-Überschwemmungsraumes in Ungarn. Acta Bot. Acad. Sci. Hung. 89: 323-385 .

KRZYWAŃSKI D. 1974. The plant communities of old riverbeds of middle part of the Warta river in Central Poland. Monogr. Bot. 43: 1-80. (in Polish with English summary)
LANDOLT E. 1982. Distribution pattern and ecophysiological characteristics of the European species of the Lemnaceae. Ber. Geobot. Inst. ETH Stiftung Rübel Zürich 49: 127-145.

MATUSZKIEWICZ W. 2005. Przewodnik do oznaczania zbiorowiska roślinnych Polski. Wydawnictwo Naukowe PWN, Warszawa. (in Polish)

MIREK Z., PIĘKOŚ-MIRKOWA H., ZAJĄC A., ZAJĄC M. 2002. Flowering plants and pteridophytes of Poland - a checklist. In: Mirek Z. (ed.). Biodiversity of Poland 1, W. Szafer Institute of Botany, Polish Academy of Sciences, Kraków, p. 442.

MÜLLER T.H. 1977. Klasse: Lemnetea R. Tx. 55 (Lemnetea minoris). In: Oberdorfer E. (ed.). Süddeutsche Pflanzengesellschaften. Teil I. G. Fischer Verlag, Stuttgart-New York, pp. 67-77.

MÜLLER T.H., GÖRS S. 1960. Pflanzengesellschaften stehender Gewässer in Baden-Württemberg. Beitr. Z. Naturk. Forschung i. Südwestdeutschland 19 (1): 60-100.

NOWAK A., NOWAK S., SPAŁEK K. 2000. Materials to the distribution of protected and rare vascular plants in Opole Silesia. Natura Silesiae Superioris 4: 23-30. (in Polish with English summary)

OBERDORFER E. (ed.) 1977. Süddeutsche Pflanzengesellschaften. 2 Aufl. 1. G. Fischer, Stuttgart-New York.

OCHYRA R. 1985. Vegetation of the karst sink-holes in the vicinity of Staszów on the Małopolska Upland. Monogr. Bot. 66: 1-136. (in Polish with English summary)

OT'AHEL'OVÁ H. 1980. Makrofytné spoločenstwa otvorených wôd Podunajskiej roviny (Trieda Lemnetea, Potamogetonetea). Veda, Bratislava. (in Slovakian)

PASSARGE H. 1996. Pflanzengesellschaften Nordostdeutschlands. I. Hydro- und Therophytosa. G. Fischer Verlag, Berlin-Stuttgart. 
POTT R. 1995. Die Pflanzengesellschaften Deutschlands. 2 Aufl. Verl. E. Ulmer, Stuttgart.

RENNWALD E. (ed.) 2000. Rote Liste der Pflanzengesellschaften Deutschlands mit Anmerkungen zur Gefährdung. In: Rennwald E. (ed.). Verzeichnis und Rote Liste der Phlanzengesellschaften Deutschlands. Schr.-R.f. Vegetationskunde 35: 393-592.

SCHRATT L. 1993. Lemnetea. In: Grabherr G., Mucina L. (eds). Die Pflanzengesellschaften Österreichs. Teil II. Natürliche waldfreie Vegetation. G. Fischer Verlag, Jena-Stuttgart-New York, pp. 31-44.

SCHUBERT R., HILBIG W., KLOTZ S. 1995. Bestimmungsbuch der Pflanzengesellschaften Mittel- und Nordostdetschlands. G. Fischer Verlag, Jena-Stuttgart.

SCHWABE-BRAUN A., TÜXEN R. 1981. Lemnetea minoris. In: Tüxen R. (ed.). Prodromus der europäischen Pflanzengesellschaften. Lief. 4. J. Cramer, Vaduz, pp. 3-141.

SENDEK A. 1984. Die Gefässpflanzen des Oberschlesischen Industriebezirks. Opol. Tow. Przyj. Nauk, PWN, Warszawa-Wrocław. (in Polish with German summary)

TOMASZEWICZ H. 1979. Roślinność wodna i szuwarowa Polski (Klasy: Lemnetea, Charetea, Potamogetonetea, Phragmitetea) wg stanu zbadania na rok 1975. Rozpr. Uniw. Warsz. Warszawa. (in Polish)

VAHLE H. C., PREISING E. 1990. Potametea-Laichkraut- und Seerosengesellschaften. In: Preising E. (ed.). Die Pflanzengesellschaften Niedersachsens - Bestandsentwicklung, Gefährdunk und Schutzprobleme. Wasser- und Sumpfpflanzengesellschaften des Süßwassers. Natursch. U. Landschaftspfl. Nieders. 20 (8): 101-128.
WAGERINGEL U., REMY D. 1997. Bedeutung von Gräben als Refugialbereich für Wasser- und Sumpfvegetation in einer landwirtschaftlich intensiv genutzten Seeniederung. Dt. Gesell. F. Limnologie - Tagungsbericht 1996: 497-501.

WITTIG R., ESSER B. 1991. Vergesellschaftung und Standortansprüche von Utricularia-Arten in Westfalen. Acta Biol. Benrodis 3: 139-154.

WOŁEK J. 1971. Distribution of the aquatic plants in the Dunajec river valley in the foreland of the Pieniny National Park. Fragm. Flor. Geobot. 20 (3): 237-250. (in Polish with English summary)

WOŁEK J. 1991. Synusial assemblages of pleustonic plants of genera: Lemna, Spirodela, Wolffia, Salvinia, Hydrocharis, Riccia and Ricciocarpus. Ber. Geobot. Inst. ETH Stiftung Rübel Zürich 57: 193-202.

WOŁEK J. 1997. Species co-occurens patterns in pleustonic plant communities (class Lemnetea): are there assembly rules govering pleustonic community assembly? Fragm. Flor. Geobot. Suppl. 5: 1-100.

ZAJĄC A., ZAJĄC M. (ed.) 2001. Distribution Atlas of Vascular Plants in Poland. Edited by Laboratory of Computer Chorology, Institute of Botany, Jagiellonian University, Cracow.

ŻUKOWSKI W. 1974. Distribution of the species of the genus Utricularia L. in Poland. Bad. Fizjogr. Pol. Zach. Ser. B - Botanika 27: 189-217. (in Polish with English summary)

ŻUKOWSKI W., LATOWSKI K., JACKOWIAK B., CHMIEL J. 1995. The vascular plants of Wielkopolska National Park. Prace Zakł. Taksonomii Uniw. A. Mickiewicza. No. 4. Bogucki Wyd. Nauk., Poznań. (in Polish with English summary) 